4

\title{
INTERSEMIOSIS NARRATIVAS Y TRANSFIGURACIONES TEXTUALES* (RITUALIDADES, OPERATORIAS, PROCESAMIENTOS)
}

\author{
“...tratar [al método] sin los privilegios del fundamento, \\ como una de las voces de lo plural, como una vista, un espectáculo... \\ engastado en el texto que es, al fin de cuentas, \\ el único 'resultado' de cualquier investigación"
}

Roland Barthes Lo obvio y lo obtuso 
Las investigaciones semióticas siempre necesitan de determinadas problemáticas comunicativas a las cuales aplicarse. Del concurso de concretas textualidades producidas en el campo social, del consumo incluso de ciertas informaciones a veces procedentes de otros territorios del saber científico. Aunque procurando salvar (casi siempre) su específica o pertinente fidelidad habida cuenta de que, en dicha instancia semiótica, se constituyen sus presupuestos y se generan sus metodologías.

En este Cuaderno del Proyecto de Semiótica abordamos el problema de las prácticas narratológicas, entendidas como sistemas complejos de producción significante en los que interactúan (se sincretizan) historias, relatos y narraciones. Las tres denominaciones (a menudo asociadas -cuando no identificadas- con una misma y sola manifestación) son en cambio reconocidas aquí de manera distintiva: como tres niveles constituyentes e interdependientes en la configuración de un complejo y compuesto objeto textual, el cual será sintéticamente caracterizado como "narrativas". Esto es, como un conjunto de acontecimientos propios de determinado contenido (narrativo), pero también como discursos (efectivamente) producidos y a la vez como enunciaciones 'situadas', que actúan de singular manera en sus particulares contextos e intertextualidades específicas.

\section{DESDE UN ABORDAJE SEMIÓTICO NARRATIVO...}

El inusitado crecimiento de lo que se ha dado en llamar (tal vez con énfasis excesivo) el giro narrativo en las ciencias del hombre y la sociedad habría de operar, en las últimas décadas, algunos cambios sustanciales en la producción de los conocimientos humanísticos y sociales, incluidos los saberes pedagógicos y didácticos. Del mismo modo, y quizás por lógica consecuencia, estos cambios habrán de incidir en todas y cada una de sus respectivas trayectorias investigativas, toda vez que unos y otros campos disciplinares parecieran haber recuperado la importancia de la narrativa como capacidad humana fundamental, y (al mismo tiempo) llamado la atención sobre el rol que desempeñan los relatos en las más diversas áreas, saberes y manifestaciones de los referidos dominios en cuestión. 
Esta recuperación de la narrativa como singular condición humana, que atañe a la vez a lo peculiar y lo genérico (como "la capacidad más profunda de cada individuo, pero también como un don universal"), motivó en cierto modo que las prácticas narratológicas hubieran actualmente devenido una de las operaciones fundamentales de construcción de sentido que posee la mente". Así, pudo sostenerse por ejemplo que "soñamos (tanto como) ensoñamos narrando; recordamos, prevemos, esperamos, creemos, dudamos, planificamos, revisamos, criticamos, construimos, aprendemos..., odiamos y vivimos por medio de narrativas" ${ }^{\prime 1}$. Ahora bien. La eventual constitución de un cierto paradigma narratológico en el dominio de las investigaciones aplicadas a las ciencias humanas y sociales ha contribuido muchas veces a establecer polos de demarcación científica entre las distintas disciplinas; cada una de las cuales, ante la necesidad de consolidar su respectivo estatuto epistemológico y metodológico ${ }^{2}$, fue signando con sesgos particulares el desarrollo de sus correspondientes prácticas o indagaciones narrativas específicas. La importancia y principales ventajas de tal paradigma incluyen sin embargo (como sostiene Arfuch) la posibilidad de construir "tramas de sentido a través de la confrontación y la negociación -entre personajes, argumentaciones, temporalidades disyuntas, lenguas diferentes, voces protagónicas y secundarias-, y articularlas en relatos cuya lógica interna sea susceptible de ser mostrada, no impuesta desde una exterioridad" (Arfuch, 2002: 196) ${ }^{3}$.

Por otra parte, aunque sin desmedro de sus indudables aportes a la investigación cualitativa, los estudios narratológicos aplicados a diferentes campos disciplinares suelen adolecer en general de un aparato conceptual-metodológico suficientemente estabilizado, que permita explicar y comprender los complejos

\footnotetext{
${ }^{1}$ Respectivamente, Robert Coles ("The call of stories: Teaching and the moral imagination"; Boston, 1989), David Lodge ("Narration with words"; Cambridge, 1990) y Bárbara Hardy ("Narrative as a primary act of mind"; Londres, 1977). Citados por McEwan y Egan (1998) en La narrativa en la enseñanza, el aprendizaje y la investigación. Buenos Aires: Amorrortu.

2 Me he ocupado especialmente de esta cuestión en el Cuaderno De signos y sentidos / 1 (2004: 18).

${ }^{3}$ Cfr. al respecto, Arfuch (2002) quien además agrega que esta "vuelta sobre la narrativa... expresa el ideal de alcanzar una voz no monológica, no investida de autoridad unilateral -lo cual no supone el espejismo de una anulación completa de jerarquías y poderes-, de lograr una ampliación del espacio del decir, en el sentido del dialogismo bajtiniano..."
} 
entramados de sentidos, contenidos y formas significantes que constituyen (y se entrecruzan en) sus procesos semiósicos de configuración y desciframiento. Haciéndose cargo de esta disyuntiva, y procurando a la vez dar alguna respuesta al mencionado dilema teórico, nuestro proyecto de investigación semiótica postula que una perspectiva reconceptualizadora del constructo-relato, que posibilite concebirlo como una estructura de significaciones en la que interseccionan diversas polifonías, y que genera recorridos heterogéneos de voces discursivas en sus procesos de producción y reconocimiento (textual), continúa subsistiendo como planteo y demandando nuevas, posibles reformulaciones... Entre las encrucijadas y problemáticas de este marco conceptual, el proyecto Travesías del sentido se propone reconocer nuevas dimensiones y categorías analíticas e interpretativas aplicadas al estudio textual y semiodiscursivo de distintos corpus de relatos verbales, audiovisivos, mediáticos, espectaculares, hipermediales, y otras construcciones narrativas del discurso social. El proyecto pretende articular así, con doble anclaje en su diseño, puestas (narrativas) en sentido (textual) y prácticas sociales correlativas, a fin de contribuir a una mejor explicación y comprensión del entramado de contenidos y formas significantes que constituyen las complejas semiosis en tratamiento.

Entre otras operaciones analíticas aplicadas al corpus textual del proyecto (conformado por textos fílmicos, teatrales, videoclípticos, hipermediales, etc.) se abordan diferentes modalidades constructivas del pensamiento narrativo subyacente a los textos en cuestión ${ }^{4}$ : sus estrategias referenciales y principales soportes o dispositivos característicos, en conjunción con una diversidad de lenguajes y discursos. Precisamente se procura atender, en cada uno de los casos, las modalidades propias de los respectivos lenguajes, códigos y discursos constituyentes, así como las particularidades que en uno y otro reviste el proceso y funcionamiento de cada sistema narrativo aplicado; conscientes, a la vez, de que no existe una metodología de análisis privilegiada, y de que es la índole misma del material textual, el propio corpus construido y los propósitos perseguidos por la investigación, los que imponen o (mejor) sugieren la forma, los caminos, los instrumentos, las operatorias de análisis e interpretación...

\footnotetext{
${ }^{4}$ A propósito de los iniciales trayectos de estas diferentes indagaciones narrativas, cfr. especialmente De signos y sentidos / 4: Las narrativas como objeto (itinerarios del proyecto). Santa Fe, Ediciones UNL, mayo de 2006.
} 
Tratando de afrontar el riesgo y no desentenderse, al mismo tiempo, de la necesaria sensibilidad de los matices y de la rigurosa responsabilidad de los recaudos. Digo: ni ejercitar lecturas que privilegien la glosa, la reducción, el aplanamiento, el corte o escamoteo (del pensar o el decir del otro, construido en el texto) ni operar con determinadas urgencias de praxis metodológica que, no pocas veces, desde la imposición de cierta rapidez conclusiva o traslativa del análisis, transmuta el caso en simple prueba de demostración o en estereotipo de pluralidad, en vez de convertirlo en fehaciente manifestación de lo que (en realidad) es: la diversa multiplicidad de lo social ${ }^{5}$.

Demandas todas (agregaré, en síntesis) de una necesaria y diferente manera de conceptualizar y de redefinir propósitos y alcances en los territorios del relato y sus indagaciones, a partir de los postulados de una perspectiva semióticonarrativa que (coincidiendo nuevamente con L. Arfuch) oriente las búsquedas, reflexiones y procedimientos de las prácticas narratológicas aplicadas al campo social hacia otras latitudes o direccionalidades. Que:

$>$ enfatice "el acontecimiento del decir, la producción dialógica del sentido, y no meramente el 'contenido' de los enunciados";

$>$ apuntale y fundamente, en consecuencia, una "intervención analítica no reduccionista ni desestructurante de las modalidades enunciativas";

$>$ haga consciente la dificultosa construcción de todo relato, "su trama a varias voces, su engañosa 'referencialidad', y por ende, la necesidad de explicitar los criterios que guiarán la indagación"; y

$>$ posibilite y genere operatorias de lectura (narratológica) direccionadas a la "confrontación de voces y relatos simultáneos (...), a una ampliación y sensibilización de la escucha, como un proceso complejo donde es importante el momento de la recolección pero también (...) el momento analítico/interpretativo" (Arfuch, 2002: 197).

\footnotetext{
${ }^{5}$ Dicho esto, sin embargo, a pesar de que "...desde escuchar lo (efectivamente) dicho o silenciado por el discurso, hasta registrar marcas del olvido o resistencias de la memoria, aún en el caso de toda utilización de citas o fragmentos, el enunciado (siempre) hace decir y la interpretación puede resultar (en consecuencia) arbitraria" (Arfuch, 2002: 198). Esto da la pauta de que existen graduaciones, matices y niveles en cualquier propósito responsable de manipulación.
} 


\section{LAS NARRATIVAS DE / SOBRE EL CINE}

Así las cosas (en general, al menos inicialmente), ¿qué ocurre con las problemáticas propias del cine y las narrativas (en particular)? Pues bien, pretender abordar el tratamiento de las narrativas fílmicas presupone interrogarse (primero) acerca de la productividad teórica, operatoria y epistémica del específico hacer cinematográfico, así como de la singular reflexividad que este hacer promueve. Quiero decir: comenzar considerando que, en definitiva, el cine habla (sobre...), del mismo modo que (o casi tanto como) es hablado (por...)

Esta doble pertinencia discursiva de las prácticas cinematográficas privilegian, por igual, su condición de (1) construcción textual (es decir, de film o registro de un discurso específico, fundado en característicos lenguajes y en dispositivos audiovisuales propios, como resultante de un singular aparato productivo) y de (2) constitución metatextual (objeto reflexivo, pertinente o no según se considere, respecto de "otros" discursos que constantemente lo asedian, aluden, refieren..., tematizan, explican, legitiman, evalúan...).

Esta advertencia incluye desde los discursos técnicos e industriales, interesados en normatizarlo como práctica, hasta los más diferentes discursos especulativos, cada uno de ellos orientado en función de determinadas exploraciones sobre la pertinencia de lo cinematográfico, que la consideran en relación con distintos ejes de reflexión: discursos históricos, estéticos, comunicacionales, sociológicos, ideológicos, económicos, institucionales, jurídicos, psicoanalíticos...

Obviamente, entre estos últimos están también los enfoques lingüísticos y discursivos, de corte analítico y crítico, que debaten aquella pertinencia en relación (por ejemplo) con los particulares territorios del lenguaje y la enunciación. Y, naturalmente, los abordajes propios de la perspectiva semiótica, que distinguen la especificidad de lo cinematográfico dentro del conjunto de los sis-

\footnotetext{
${ }^{6}$ Cfr., por ejemplo la nómina de textos iniciales de consulta y apoyatura teórico-metodológica que fueran incorporados a las referencias bibliográficas de una propuesta investigativa. Nota de la Edición: ver "Enunciación, expectación y narrativas audiovisuales" en esta Parte III, cuando Caudana sostenía que dicho diseño de investigación surgía del "inusitado interés que ha despertado en los últimos años el estudio sobre las problemáticas enunciativas, espectatoriales y narrativas (así como la importancia de los aportes efectuados) en el dominio de los análisis discursivos y textuales aplicados al campo audiovisual." (Caudana, 2005: 65).
} 
temas productores de sentido (al pensarlo en términos de interrelación, síntesis y síncresis de lenguajes, formatos y dispositivos diversos), y que promueven toda una serie de variadas operatorias analíticas, decodificadoras e interpretativas. La aparición de la semiótica del cine a mediados de la década del setenta, y sus novedosos planteamientos acerca de una necesaria aproximación metódica al análisis de los filmes, de un abordaje sistemático y del empleo riguroso de un conjunto de categorías bien definidas... provocó una serie de resistencias y de aprobaciones que (en algunos casos) reestructuraron posiciones en el campo de la reflexión teórica propia de la época, como fue en el caso de los discursos aplicados que procedían de la psicología y la sociología.

Del cruce de opiniones surgieron posturas decididamente encontradas a punto tal que, como sostiene F. Casetti, lo que la semiótica del cine procuraba definir como voluntad científica se trasformó para algunos en indudable "signo de progreso", pero para otros, en un tópico de incuestionable "aridez"; la preferencial atención puesta en "los instrumentos más que en los objetos de análisis [fue] para unos la excusa para alejarse de la realidad concreta del cine, y para otros una forma de rigor; su indiferencia por el debate anterior [representó] para unos una prueba de autonomía, y para otros, una mera presunción" (Casetti, 2000: 153).

De todos modos, esta decidida identificación y defensa del método permitió, a la incipiente semiótica del cine, instalarse rápidamente en un auténtico sitial de privilegio dentro del concierto de las teorías acerca del espectáculo fílmico: ciertamente en un primer lugar, teniendo en cuenta su actitud comprehensiva respecto de la problemática de conjunto, y como posicionamiento ejemplar, en tanto búsqueda de un estilo propio de investigación en el campo. Algunos de los ensayos iniciales de Christian Metz son generalmente reconocidos como pioneros e inaugurales de esta corriente investigativa, precisamente por su definido rechazo a los desarrollos esencialistas, además de su marcada adhesión a una actitud de aproximación metódica al objeto de estudio. Es el caso, por ejemplo, de "Le cinéma: langue ou langage?", aparecido en 1964 en la revista Communications / 4, "La grande syntagmatique du film narratif" (Communications / 8) y "Le dire et le dit au cinéma" (Communications / 11), los dos primeros, posteriormente incorporados a sus Essais sur la signification au cinéma (1968). Al primero de dichos ensayos lo ocupan, en particular, 
recorridos y alternativas de dos problemáticas de fondo. La primera: diversos planteamientos a propósito de los límites y objetivos del dominio de estudios cinematográficos $\mathrm{y}$, especialmente, la pregunta acerca de si el cine podría constituirse en un fenómeno adecuado para el análisis semiótico ${ }^{7}$, habida cuenta de la pertinencia de sus instrumentos de análisis. La segunda resulta aún hoy, sin duda, más específica: si ante los problemas propios de investigación sobre lo fílmico nos estamos situando frente a una cuestión de lengua (es decir, un repertorio codificado de símbolos, figuras o fórmulas a las cuales podemos hacer constante referencia) o de lenguaje (esto es, un discurso hasta cierto punto espontáneo y autorregulado).

"Hay que crear una semiología del cine", postula sin embargo abiertamente Metz (1968: 139); en cuanto a su definición por el dilema inscrito en el título del ensayo, y a pesar del contexto (fuertemente) estructuralista en el que se desarrollan estas primeras aproximaciones, se pronuncia a favor de lo fílmico como lenguaje. Para Metz el cine no es una lengua pues (a diferencia de las lenguas naturales) no posee el rasgo fundacional de la "doble articulación" ni satisface plenamente los elementos definicionales que la caracterizan. Ni el cine posee unidades fijas de sentido (cada encuadre, por ejemplo, constituirá siempre un caso en sí mismo), ni unidades carentes de significado (cada parte de un determinado encuadre, posee ya un sentido).

A pesar de esta aparente o relativa contradicción según la cual, por no poder ser asociado el cine con las características propias de una lengua (régimen oposicional, arbitrariedad de sus significantes, etc.) carecería en principio de interés para el análisis semiótico o semiológico, Metz propone y legitima el reconocimiento de una opinión contraria, que "consiste en concebir la empresa semiológica como una investigación abierta, a la que no le esté vedado asumir aspectos nuevos; el 'lenguaje' (en el sentido más amplio del término) no es cosa simple, y los sistemas flexibles pueden ser estudiados, en cuanto sistemas flexibles, a través de métodos apropiados" (Metz, 1968: 135 -136).

\footnotetext{
${ }^{7}$ En sentido estricto se hablaba entonces de determinadas adecuaciones y requerimientos de un análisis semiológico, teniendo en cuenta el predominio y plena vigencia de la lección saussureana y la lingüística estructuralista. Precisamente en Comunicaciones / 4, en el que aparece "El cine: ¿lengua o lenguaje?", Ilevaba por título La semiología.
} 
Lo cierto es que la propuesta exploratoria de Metz suscitó un inmediato y amplio debate en el que participaron, entre otros, Eco, Bettetini, Garroni,. Pasolini, etc. ${ }^{8}$ hasta que, ya hacia principios de los '70, la semiótica del cine pudo ser considerada como un dominio de estudios en plena expansión, con un conjunto de investigaciones que procuraban dar cuenta de las problemáticas extensivas del campo. Desde la codificabilidad del discurso cinético y sus vinculaciones con los restantes lenguajes (Lotman, Ivanov) hasta la especificidad de los respectivos materiales fílmicos (Helman, Brunetta), pasando por las retóricas de la imagen, las relaciones entre lenguaje y realidad, las estrategias del análisis discursivo, la utilidad de la semiótica para la crítica espectacular, etc.

Si la transición de los '60 a los '70 merece ser considerada como la de años de expansión de la semiótica cinematográfica, del ensanchamiento y ampliación de sus iniciales marcos de referencia, los años posteriores podrían ser caracterizados como los de una etapa de dispersión. Efectivamente, las orientaciones de la nueva semiótica y del denominado giro textual aperturan las investigaciones del cine hacia otros intereses. Desde la necesidad de desmontar ideologías dominantes (con su consecuente acercamiento a los ámbitos reflexivos del psicoanálisis y el marxismo, y su distanciamiento crítico de los planteos taxonómicos del estructuralismo)..., hasta diferentes indagaciones interesadas por áreas cada vez más restringidas o específicas: la cuestión de los géneros fílmicos, el ámbito productivo y los aspectos de la industria cinematográfica, el análisis de las películas concretas, etc.

En rápida síntesis podría decirse que la noción de sistema será progresivamente sustituida por la de proceso, y terminará por redefinirse el objeto de estudio: la preocupación teórica y metodológica se desplazará ahora del trata-

\footnotetext{
${ }^{8}$ No es mi intención (por lo menos aquí) detenerme en los avatares, encrucijadas y desarrollos programáticos de una (meta)narrativa teórica sobre el cine, actualmente en proceso de elaboración, por lo que sólo mencionaré un par de circunstancias más. Sin embargo, más allá de lo anecdótico, no es casual esta participación casi exclusiva de semiotistas italianos a través de este conjunto de primeras exploraciones y contribuciones. Es precisamente en Italia donde comienza a desarrollarse la corriente semiótica fílmica, a partir de numerosos aportes efectuados en dos congresos internacionales dedicados al lenguaje del cine, en 1966 y 1967, los que tuvieron lugar en el marco de la Mostra del Nuovo Cinema de Pesaro. Las actas de ambos congresos, con el registro de importantes intervenciones de los autores citados, fueron posteriormente reeditadas en 1989 bajo el título Per una nuova crítica. I convegni pesaressi/1965-1967. Venecia: Marsilio.
} 
miento del cine como campo de posibilidades, al análisis (grupal o individual) de los textos fílmicos como dominio de realizaciones. Una vez más, al lado de este nuevo conjunto de intereses, reaparecerá la cuestión narrativa que en realidad nunca dejó de preocupar a la semiótica cinematográfica.

Desde la revisión de las tipologías iniciales de Metz hasta las nuevas contribuciones de Gardies, Jost y Gaudreault, se amplía entonces el horizonte de las indagaciones narratológicas fílmicas, afincándose ahora en problemáticas tales como las del acto mismo de narrar, la funcionalidad de la enunciación y la construcción del punto de vista, capaces (unas y otras) de anclar el relato cinematográfico y de asignarle a la vez un sesgo u orientación determinada. De manera simultánea a estos desarrollos, y partiendo de considerar la construcción del texto fílmico como un conjunto de virtualidades, algunas investigaciones posteriores examinan los modos en que el texto evidencia su proyecto comunicativo subyacente y organiza el flujo informativo: tal el caso, por ejemplo, de algunos intentos (como los de Chateau y Colin) de aplicar al cine los modelos de las gramáticas generativo-transformacionales.

De las postrimerías de una segunda semiótica se opera así, en las últimas décadas, un deslizamiento de los intereses teóricos y metodológicos (ahora caracterizados como post-semióticos), hacia nuevos recorridos abiertos y de movimiento centrífugo, aunque siempre atentos a las dinámicas e implicaciones del texto fílmico. Un ámbito de estudios que se nos presenta como sumamente rico en posibilidades, tanto por la trayectoria en la que se inscribe como por las innovaciones que propone.

Desde la ampliación de sus intereses hasta la recuperación de sus mejores tradiciones, desde la búsqueda de nuevas fuentes de inspiración hasta la disputa por establecer encuentros comparativos con otras formas de investigar en el campo...

\section{DEL LEER (Y DEL DECIR, RESPECTO DE) UN NARRAR FÍLIMICO}

Efectuaré, a partir de aquí, una serie de sucesivos recortes al interior de este ordenamiento general de consideraciones semióticas referidas al cine como construcción discursiva. Propiciar por ejemplo la lectura crítica de un texto 
fílmico (de todo texto audiovisual, en realidad) debiera consistir, básicamente, en desmontar la aparente naturalidad de las imágenes, en discutir la supuesta transparencia de su proceso de producción. En tanto que sistema (específico) de representación, toda película cinematográfica podría ser así considerada como la evidencia o manifestación (textual) de un dinámico proceso de formalización de ciertas categorías significativas, a menudo implícitas o subyacentes.

Como la forma (específica) de un contenido, en definitiva: de una construcción narrativa y discursiva que (además) conceptualiza, clasifica y organiza reglas, comportamientos y convenciones sociales que se traducen en diferentes prácticas (culturales, institucionales, estéticas, políticas, etc.) desarrolladas en determinados contextos...

Teniendo en cuenta que tales regularidades, códigos y convenciones no se limitan, en el caso de la textualidad fílmica, a lo que habitualmente se concibe como el contenido de una película (lo-representado), sino que abarca al cómo se construye ese contenido (el-sistema-de-representación) ${ }^{9}$, nuestro abordaje del objeto de estudio ${ }^{10}$ procurará dar cuenta, progresivamente y a la vez, de tres contextos de manifestación, concebidos como tres instancias de permanente interacción y negociación de significados:

$>$ las circunstancias de producción textual (contexto de enunciación)

$>$ la conformación semiótico-estructural del texto (interacciones texto/contextos), y

$>$ los niveles de consumo, reconocimiento y audiencia (contexto de recepción textual).

Considerada entonces en términos de semiótica textual, la índole narrativa de nuestro objeto-problema podría ser reconstituida (al menos, en una primera instancia) a través de un complejo recorrido generativo de significaciones que, a partir de estructuras subyacentes de sentido, aflora o se manifiesta a través de un proceso de productividad en el que se articulan e interactúan diferentes

\footnotetext{
${ }^{9}$ El deslinde de lo representado y el sistema (fílmico) de representación anticipa aquí la posterior distinción entre diégesis y discurso, habida cuenta de su inclusión en una segunda dimensión analítica de la diferenciación establecida entre relato y narración.

${ }^{10}$ Las consideraciones en otra oportunidad efectuadas, a propósito de los documentales cinematográficos (Caudana, 2004: 63), pueden extrapolarse aquí al discurso audiovisual (en general) y a los textos fílmicos (en particular).
} 
componentes del contenido y de la expresión fílmicas: acciones, personajes, espacios, tiempos, enunciaciones, focalizaciones, etc.

Dichas travesías narrativas del sentido (modalidades, estrategias y efectos de dicho proceso configurativo del objeto denominado texto fílmico) podrían ser analizadas e interpretadas, en esta particular concepción, desde (por lo menos) seis perspectivas teórico-explicativas complementarias de abordaje: desde una analítica, una morfología, una taxonomía, una poética, una retórica y una pragmática textual ${ }^{11}$ :

> La primera se ocuparía de identificar las unidades del sistema y del proceso fílmico, y de detectar el comportamiento funcional e interactivo de las mismas.

$>$ La segunda perspectiva procuraría caracterizar los patrones u observables que constituyen la particular estructura (sintagmática) del texto fílmico.

> La tercera permitiría clasificar y tipologizar o, por lo menos, establecer algunos parámetros o principios de organización paradigmática del corpus.

$>$ La cuarta y la quinta favorecerían la reflexión acerca de las normatividades caracterizadoras del complejo textual (lo invariable, digamos), y también sus variantes estratégicas y estilísticas. Esto es, lo creativo y lo transgresor o lo transgredido en el proceso fílmico: las operaciones retóricas que lo enriquecen, las posibles lecturas interpretativas que lo abarcan, etc.

$>$ La sexta perspectiva complementaria, finalmente, por situarse en un paradigma de comunicabilidad textual, permitiría estudiar las diferentes relaciones existentes entre los signos cinematográficos, sus potenciales intérpretes y usuarios empíricos.

El siguiente (primer) acercamiento propuesto a las problemáticas del filme concebido como signo textual narrativo, incluye aspectos y componentes de estas diferentes perspectivas de abordaje, pero adopta (de manera particular) los que corresponden a los dos primeros enfoques, el analítico y el morfológico.

Este recorte y selección de perspectivas deviene de la singular conceptuación de modelo que sustenta la propuesta, en tanto que se direcciona a la atenta observación e identificación (en un determinado texto cinematográfico) de las unidades

\footnotetext{
${ }^{11}$ La posterior propuesta, referida a la primera versión (semiótico-estructural) de una eventual gramática narrativa, reformula y articula algunas de estas caracterizaciones generales. Cfr. al respecto J. G. Jiménez (1996).
} 
que lo conforman como sistema de producción significante y como proceso narracional, a la vez que permite reflexionar acerca del específico comportamiento funcional e interactivo de las propias unidades constitutivas de dicho sistema.

\section{ASEDIOS AL OBJETO DESDE LAS GRAMÁtICAS DEL CINE ${ }^{12}$}

Consciente de estar abordando el problema desde una perspectiva sesgada (en definitiva, insuficiente), procuraré delimitar a continuación un posible primer modelo analítico, de base semiótico-estructural, que pretenderá ser posteriormente enriquecido por otras aproximaciones. Este inicial planteamiento intenta recuperar (como ya dije) algunos presupuestos y contribuciones de los denominados modelos gramaticales, tanto aquellos referidos al estudio sintáctico de los encadenamientos narrativos, de fundamento lingüístico, como de otros aportes superadores de ese marco analítico, que buscan justificar sus correspondientes sintagmáticas a partir de la identificación y el aislamiento de códigos audiovisuales específicos. No obstante aquellas primeras cautelas, se

\footnotetext{
12 La incorporación del enunciado "modelo gramatical narrativo" demandaría en realidad explicitar unos cuantos supuestos, que alcanzaran a dar cuenta suficiente de algunos estrictos recaudos y reservas adoptadas. Sólo diré por ahora que la noción de "modelo" es aquí utilizada en su acepción de representación simplificada y abstracta de aspectos característicos de un fenómeno real complejo, como es sin duda el caso de las narrativas fílmicas. Dicha "representación", sustentada en determinadas teorías e hipótesis, debiera facilitar la descripción más o menos exhaustiva del fenómeno en consideración, de las normas y principios específicos que lo configuran (de la "predecibilidad" de su funcionamiento sistémico y procesual, por ejemplo), y permitir a la vez evaluar la eficacia de ciertos resultados a través de su aplicación. Respecto de la mención "gramáticas narrativas", las mismas reconocen diferentes procedencias de la lingüística estructural y transformacional (N. Chomsky, por ejemplo, asociaba "modelos" con "gramáticas") y presuponen que, así como todo texto narrativo consta de determinadas unidades específicas, organizadas de acuerdo con un conjunto de reglas, es posible describir el funcionamiento estructural de tales textualidades del mismo modo en que se describe la organización de las lenguas naturales. Sería el caso por ejemplo de diferentes autores que (como los iniciales Barthes, Todorov, Greimas, Hendricks, entre otros, a propósito de la teoría literaria, y sólo en principio) han procurado esbozar una gramática textual narrativa apoyándose en determinadas unidades básicas, las cuales se corresponden con categorías propias de la estructura sintáctica oracional, explicitando además las reglas que presiden ese encadenamiento y estableciendo a priori los tipos posibles de articulación secuencial resultantes. Cfr. Análisis estructural del relato, Semántica estructural, Literatura y significación, Gramática del Decamerón, etc.
} 
tratará asimismo de proponer una aproximación (analítica, gramatical, sintáctica... pero) sustentada en una idea constructiva de relato.

En términos más específicos: una compleja fenomenología textual concebida como proceso generativo que sólo puede ser comprendido e interpretado si se lo acompaña en su recorrido y se lo aborda con una mirada integradora, en su intrínseca dualidad de acontecer-narrado (historia, en tanto contenido formalizado) y de forma-de-ser-contado (discurso, en tanto forma expresiva). Quiero decir: identificando los diferentes códigos que se implican en su funcionamiento, y estableciendo entre ellos las relaciones que manifiestan o evidencian la polifonía textual que soporta y constituye la estructura del relato. Esta propuesta modélica gramatical-procesual para el análisis de los textos cinematográficos parte, en consecuencia, del supuesto de que lo sistémico (aquí, en una doble acepción, configurativa e indagatoria) constituye el modo propio y específico de organización y funcionamiento de las narrativas fílmicas. En tal sentido, numerosos autores (Bataille, Dreyfus, Metz, Pasolini, Sadoul, Spottiswoode, Thenon, Vanoye, entre otros) se han dedicado en las últimas décadas al estudio de los lenguajes, las gramáticas y particulares sintaxis del universo audiovisual en general, y del cinematográfico en especial. Ahora bien: reflexionar a propósito de la sintaxis narrativa como modalidad característica de articulación secuencial de las acciones y acontecimientos (narrativos) presupone, en este modelo gramatical, la distinción teórica entre historia y discurso. Importa distinguir entre qué se narra y cómo, o entre contenido formalizado y forma de la expresión, por cuanto es en el nivel de la historia y, en sentido estricto, en el plano de las unidades nucleares y funcionalmente pertinentes que la constituyen, donde (de manera inestable y problemática) se ubica la cuestión sintáctica.

La formulación de la pregunta acerca de si es posible analizar el encadenamiento sintagmático de las secuencias narrativas, empleando la sintaxis así como la concibe el modelo gramatical aplicado a las lenguas naturales, requiere sin embargo establecer una serie de matizaciones previas, a propósito de la incidencia (por ejemplo) de los parámetros temporales y lógicos en el proceso de estructuración de los eventos que componen el nivel de la historia ${ }^{13}$.

\footnotetext{
${ }^{13}$ Los posformalistas rusos (Propp, por caso) sostienen la irreductibilidad del orden cronológico y la prevalencia del factor "tiempo" en la construcción estructural del sistema narrativo; los estructuralistas franceses (el caso de Bremond) postulan en cambio una "lógica elemental" de las acciones o comportamientos habituales que, combi-
} 
La postura de Todorov puede ser considerada, en este sentido, una propuesta integradora o sincrética acerca de los avances y contramarchas en la constitución del acontecer narrado. Según esta postulación, la sintaxis narrativa conjugaría a la vez una lógica de la sucesión, o de la conexión causal y/o temporal de las acciones funcionales, y una lógica de la transformación, o del establecimiento paradigmático de relaciones opositivas entre semejanzas y diferencias de los respectivos aconteceres o comportamientos considerados.

Otros autores, como Dolezel, sostienen en cambio que el abordaje sintáctico de la composición de las historias no debiera sustentarse en criterios de temporalidad y/o logicidad, en parámetros de consecución y/o consecuencia, sino en principios de homogeneidad modal a partir de los cuales los relatos complejos podrían ser descompuestos en átomos narrativos, organizados en torno de una serie finita de modalidades: motivos de posibilidad (historias aléticas), de autorización (deónticas), de valor (axiológicas), de conocimiento (epistémicas)... En otras direcciones relativamente afines con estos desarrollos, algunos autores (como Metz ${ }^{14}$, por ejemplo) han planteado la existencia de una doble identificación cinematográfica del espectador; aunque dichas identificaciones tienen en realidad menos que ver con efectos de relación psicológica(la identificación con tal o cual personaje de ficción, por caso) que con efectos estructurales del mismo texto fílmico (la circulación de las identificaciones, por ejemplo debido a la rotación de diversas técnicas de découpage y la progresiva selección de diferentes puntos de vista). Así es que otros autores (como Aumont y su equipo de colaboradores ${ }^{15}$, por ejemplo) han destacado, como previa a cualquiera de

nados en secuencias complejas, permiten formular modelos deductivos sobre una gama de "posibles narrativos".

${ }^{14}$ Transponiendo la tópica freudiana al terreno cinematográfico, Metz (1979), entre otros autores, han planteado la existencia de una doble identificación cinematográfica del espectador. Con la cámara, en primer lugar, en tanto mirada (que ha-visto-antes lo que él está mirando-ahora), y que lo coloca en una posición de omnipotencia. En segundo lugar, con el desdoblamiento de su propio saber o conocer: por un lado, el espectador es consciente de encontrarse ante un espectáculo (imaginario, ficcional, artificial...) frente al cual adopta una posición pasiva y externa; pero por otro, esta percepción de "lo real" (esta identificación -activa, interna-con el acto mismo de la percepción) reconstituye el imaginario percibido como continuidad en el interior mismo del sujeto.

15 Cfr. Aumont, Bergala, Marie y Vernet (1989). La razón de ser de tales identificaciones se encontraría en la analogía existente entre las estructuras fundamentales de todo relato y la estructura edípica, según fuera formulada por Freud: todo relato ejemplificaría así el conflicto básico existente entre el deseo y la ley. 
estas identificaciones, la existencia de lo que denominan una identificación primordial con el relato que, en todo caso, el cine compartiría con las restantes artes narrativas. Del mismo modo que en el caso de esta vinculación primordial o primaria, la identificación con el relato pareciera revelarse como condición indispensable para que el film mismo pueda elaborarse. Todo lo cual vuelve a remitirnos a los trabajos pioneros de semiótica textual, narrativa y discursiva de la Escuela de París (Greimas, Courtes, Odin, entre otros) cuando se instala la narratividad como base estructural del sentido: de lo narrativo, en cuanto tal, como proceso y fundamento de toda construcción (textual) de sentido ${ }^{16}$ (y no sólo de los mitos o cuentos tradicionales, ni siquiera sólo de los relatos que se generan en relación con una textualidad literaria).

Sin pretender por ello dictaminar o concluir sobre el agotamiento de esta tradición narratológica (con respecto a cuestiones sintácticas posibles de ser aplicadas a la construcción narrativa fílmica), sólo mencionaré finalmente la postura de un cineasta y teorizador ubicado en las antípodas de las anteriores aproximaciones lingüísticas al problema. Me refiero a Pier Paolo Pasolini quien sin embargo ha pretendido gramaticalizar el cine, entendiéndolo como cinelengua y a las películas como momentos escritos o meros registros de una lengua prexistente: la lengua de la acción. Siguiendo el modelo (verbal) de la doble articulación lingüística, Pasolini propone articular, a través de la lengua del cine, monemas (unidades significativas, equivalentes a los encuadres) y cinemas (objetos y acciones de la realidad, en tanto portadores de significación), a partir de los cuales sienta algunos basamentos para la elaboración de una gramática cinematográfica, complementaria de una retórica y una estilística fílmica. Para decirlo con palabras del crítico Saltini: así como "Barthes quiere utilizar la lin-

\footnotetext{
${ }^{16}$ Vale recordar aquí que, en una etapa posterior de su producción teórica y metodológica, los nuevos aportes o reformulaciones de la semiótica greimasiana procuraron superar aquella primera instancia puramente heurística del saber textual (un diversificado conjunto de procedimientos sistemáticos, destinados a la decodificación de la materialidad significante del texto) proyectándola, en esta segunda, hacia las más diferentes formas y los modos más generales del razonamiento discursivo. Esta reorientación de la teoría se capitaliza, entre otros sentidos o direcciones fundamentales, cuando al reconceptualizar las categorías iniciales, trasciende los estudios narratológicos y hace extensiva la idea de narratividad a todo depósito de formas de significación: a una estructura o mecanismo que subyace a toda actividad humana significante. Relacionado con esto, cfr. lo expresado al final de este trabajo.
} 
güística científica, la de los lingüistas; [este] último y más impenitente gramático del cine [Pasolini] aplica, en cambio, su lingüística particular y personal".

En cualquiera de los casos mencionados, la sintaxis aparece siempre considerada como una componente esencial del código lingüístico, y sus unidades mínimas se convierten en instrumentos específicos del análisis textual narrativo. Pero lo cierto es que, en el compuesto entramado de la discursividad cinematográfica, no existe un código soberano que pueda imponer sus mínimas unidades (a los restantes) para el análisis textual. Contrariamente, los filmes se ofrecen a través de una superficie textual sumamente compleja, temporal y espacial a la vez, en la que intervienen y participan multiplicidad de códigos y subcódigos; y cada uno de ellos posee sus propias unidades analíticas las cuales, a lo largo del discurso que los constituye se superponen, imbrican, solapan sin que sus límites, bordes o fronteras coincidan forzosa y necesariamente.

Esto es, en buena medida, la empresa iniciada décadas atrás ( $y$, una vez más, posteriormente enriquecida) por Christian Metz, para quien el análisis narrativo fílmico no puede fundarse en una sintaxis de base lingüística sino en una gran sintagmática ${ }^{17}$. Esta contundente aseveración implica operar un cambio teórico, epistémico y metodológico esencial, que reemplace las unidades materiales (los lenguajes, el verbal entre otros) por las unidades de pertinencia: el aislamiento de los principales códigos y subcódigos cinematográficos y, a partir de ellos, determinar las unidades mínimas que corresponden a cada uno.

A manera de ejemplo. Sea que se lo considere desde la perspectiva narrativa (esto es, como secuencia de acontecimientos), sea que se lo analice desde un punto de vista formal o material (como articulación de planos, por ejemplo), el relato fílmico constituye un gran sintagma cinematográfico que puede ser dividido en segmentos menores o unidades mínimas (no sintácticas), susceptibles de aparecer en diversas combinaciones. Dichos segmentos sintagmáticos autónomos (la denominación también corresponde a Metz) constituyen subdivisiones fílmicas de primer nivel, o sea no dependientes de subdivisiones anteriores, y pueden ser reagrupados en seis tipos básicos: la escena, la secuen-

\footnotetext{
17 "La gran sintagmática del film narrativo" se denomina, precisamente, el artículo incorporado por Metz al volumen colectivo (Barthes, Bremond, Greimas, Todorov y otros) de "Análisis estructural del relato", Revista Comunicaciones / 8, Ed. Du Seuil, 1966. Cf. versión castellana (1972) Buenos Aires: Tiempo contemporáneo.
} 
cia, el sintagma alternante, el sintagma frecuentativo, el sintagma descriptivo y el plano autónomo.

La escena, por caso y a la vez analogía con el teatro, es la reconstrucción por medios fílmicos de una unidad concreta (un lugar, un momento, una pequeña acción particular...) y, desde el punto de vista de su funcionalidad narrativa, definible "según una determinada configuración de personajes" (Metz), intercambios de acción, etc. Es en la escena, dice González Requena:

"donde la escritura fílmica produce su efecto de sentido de base: la representación. En la escena se despliegan la gran mayoría de los parámetros significantes del film: parámetros de interpretación, de iluminación, de movimiento de cámara y de objeto, de planificación, de encuadre y de composición (...). En el cine (por lo menos, el que responde al modelo representativo-narrativo) sólo comienza a existir (el) sentido a partir de la escena y, más exactamente, a partir de su clausura. Por debajo de ella pueden existir significados denotados por las imágenes pero nunca sentido... Sólo con su cierre, la escena se ordena en sistema y sus significantes son recubiertos de sentido." (González Requena, 1980)

También en términos de Eco, el "lenguaje audiovisual" (según su concepción: un mero y simple enunciado metafórico, que ha servido para referirse al aspecto comunicativo de los mensajes difundidos por los medios audiovisuales) se ha convertido en objeto de análisis semiósico sin haber sido antes identificados los signos que lo caracterizan y los códigos que lo rigen. Es que, en la discursividad audiovisual, entendida como complejo sistema de producción significante, intervienen diferentes códigos y (éstos, a su vez) de diversa índole, entre los cuales (y sólo como una especificación más, entre otras tantas) participan los códigos lingüísticos.

Entre las demás series que constituyen lo cinematográfico, pueden reconocerse por ejemplo los códigos tecnológicos, visuales, sonoros, de montaje, etc., cada uno de ellos (como ya se dijo) con sus correspondientes subcódigos y materialidades expresivas o significantes: tipos de planos o de angulaciones, operaciones y tipos de montaje, etc. Negar en consecuencia la competencia discursiva de las imágenes, cuando el cine lleva ya (y a través de ellas) más de un siglo narrativizando historias, sería (precisa y paradójicamente) negar una 
evidencia histórica. Queda claro entonces que, desde un punto de vista teórico tanto como operacional, un exclusivo análisis sintáctico del texto fílmico resultaría innegablemente reduccionista.

El camino de la sintaxis (al menos, de la sintaxis lingüística o gramatical, en sentido lato) aparece, en síntesis, como escasamente productivo en el ámbito cinematográfico, toda vez que "la imagen, considerada como signo textual, no refleja un simple objeto del mundo natural sino un objeto procesado conceptualmente y culturalmente conformado. No existe, pues, la imagen pura, la imagen denotativa, y ello constituye un terreno especialmente versátil y movedizo para las pretensiones lingüísticas y semiológicas..."18

La tentativa por definir (en términos formales) los principios que rigen el montaje y la organización de las unidades sintácticas insinúa y privilegia, no obstante, la existencia de macroestructuras textuales en la configuración, cohesiva y coherente, de una textualidad narrativa fílmica. Pero los textos audiovisuales (en general aunque particularmente los cinematográficos) son textos muy complejos, que oponen resistencias a una cerrada catalogación de funciones y reglas combinatorias. Por un lado, sus implicaciones semánticas no se agotan en una mera funcionalidad contenidista, ya que proliferan a través de expansiones discursivas no narrativas: ciertas descripciones, algunos diálogos, determinados comportamientos e indicios, etc. Por el otro, acusa la permanente intervención de numerosos factores extralingüísticos que, en principio, tampoco podrían ser dimensionados como narrativos: algunas convenciones propias de los géneros, las coordenadas espacio-temporales de determinada época, ciertas rutinas culturales, etc.

Por lo cual pareciera, al menos hasta acá, que el problema de la formalización de los modelos narrativos fílmicos tendría que ser abordado dentro del marco de un encuadramiento reflexivo mayor, o bien en una instancia posterior a la de estos planteamientos gramaticales. Además, con una definida referenciación a los sistemas de modelización de la cultura, en la medida en que la lógica de las narrativas forma indudablemente parte de la lógica de los códigos humanos:

18 "... dignas de mejores causas", según concluye Jesús García Giménez en Narrativa audiovisual (1996: 39), a quien particularmente seguimos en este relevamiento. 
esto es, de los comportamientos humanos, de las ideologías, de las subjetividades, de las interacciones sociales... ${ }^{19}$

\section{ACERCA DEL FILME Y NUEVAS FORMAS DE LA SIGNIDAD}

Otras reflexiones epistemológicas efectuadas a propósito de nuestro objeto insisten, sin embargo, en la posibilidad (o en la necesidad, según el caso) de proyectar nuevos abordajes sintácticos o gramaticales sobre las narrativas cinematográficas. En la situación que particularmente me interesa, desde la perspectiva de una lingüística externa por ejemplo: en tanto que la imagen constituye y puede ser analizada como un texto, en el sentido en que lo consideran Hjelmslev y la escuela glosemática. Esto es, como un "conjunto finito y analizable de signos..."20. Desde dicha perspectiva no sólo tendrían sentido los enfoques descriptivos y explicativos de una lectura (textual) analítica e interpretativa de las imágenes fílmicas. Por el contrario, la conceptualización de la imagen como texto permitiría fundamentar tanto los principios de una gramática intratextual del filme (que estudiaría y analizaría la constitución y relaciones existentes en-

\footnotetext{
${ }^{19}$ A diferencia de las perspectivas textualistas de tradición saussureana (desde Jakobson a Barthes, pasando incluso por Hjelmslev, a quien reconsideraremos a continuación), o de sus variantes metasemióticas y generativas (Genette, Greimas) las cuales, con sus diferencias o matices, restablecerían igualmente modelos teóricos y descriptivos de base lingüística, I. Lotman y los semiotistas de la Escuela de Tartu representarían una orientación semiocultural en la conceptualización del texto. El texto lotmaniano (constructo teórico en el que estoy pensando cuando postulo la necesidad de nuevos replanteos para esta cuestión) constituye una unidad finita, cerrada desde el punto de vista formal, aunque heterogénea y dinámica en cuanto a los diferentes códigos y lenguajes que permite ingresar a su sistema, a su vez organizados de maneras diversas y en múltiples combinaciones. Cf. asimismo M. Bajtin y la noción de enunciado plurigenérico y plurilingüe.

${ }^{20}$ En términos lingüísticos, Hjelmslev utiliza la noción texto para designar la totalidad de una cadena lingüística, en principio ilimitada si se tiene en cuenta la productividad del sistema. El reconocimiento de unidades máximas recurrentes permiten analizarlo y establecer el tipo de lingüística o de gramática por constituir: así, elegir el discurso como unidad máxima recurrente del texto dará lugar a la construcción de una lingüística discursiva. En tanto representación semántica el texto es indiferente a los modos de manifestación semióticos (que son lógicamente ulteriores). El texto espectacular, por ejemplo, comprende el conjunto de lenguajes de manifestación (entonación, gestualidad, mímica, proxémica, programación cromática, juegos de luces, etc., además del verbal) a los que recurre.
} 
tre los signos componentes de la imagen) como los de una gramática inter o transtextual (que se abocaría al estudio de los entrecruzamientos, localizados, en principio, en la superficie de los textos cinematográficos, de los códigos de la sociedad, de la cultura, de la historia...).

La adecuada profundización de estas posibles perspectivas y sus correspondientes nuevas demandas teóricas y metodológicas requieren, no obstante, por lo menos una rápida consideración previa respecto del importante problema conceptual de la representación: cuestión clave en torno del debate acerca de la significación de las imágenes (en general) cinematográficas (en particular). Más allá de los activos desacuerdos existentes entre las asociaciones del concepto de representación con los de semejanza y/o de sustitución ${ }^{21}$, cualquiera de las dos hipótesis precisa de (por lo menos) dos condiciones para su eventual validación. La una: que las formas autoricen a los significados con que se las inviste; la otra: que los contextos los legitimen (a los significados adjudicados)... En otras palabras: una forma que significa de una particular manera en determinado contexto, puede significar diferente dentro de otro contexto. Quiere esto decir que, en cualquiera de los dos casos, se estaría subrayando el carácter tentativo, provisional de la articulación existente entre la expresión y el contenido de una imagen, o bien de una secuencia de imágenes (sean éstas fijas o móviles). Etc., etc.

Dicho en otros términos, seguramente más precisos: los sistemas de significación (narrativos, icónicos, etc.) pueden ser pensados como desarrollos subyacentes a los procesos de comunicación más o menos estandarizados (audiovisual, cinematográfica, por ejemplo); y un estudio circunscripto tanto a uno como a otro objeto (lo comunicativo o lo significativo) puede resultar independiente del otro, sin que esto niegue la posibilidad de que uno u otro pueda plantearse como su abordaje complementario. Con lo cual se amplificaría

\footnotetext{
${ }^{21}$ Más allá de las importantes disquisiciones y argumentos fundados en favor de una u otra conceptualización, suele predominar la asociación del concepto de representación con el de sustitución, que a su vez engloba la noción de semejanza sin reducirse a ella. Esto es: siempre que exista semejanza habría sustitución, aunque la primera no fuera condición necesaria para la segunda. Dado que, como dijo Barthes, la representación no se define por la imitación, y que existe más allá de lo "real", lo "verosímil" o la "copia", habría una identificación profunda entre representación y significación.
} 
el campo del análisis de las narrativas fílmicas, toda vez que de acuerdo con estos puntos de partida, como dice Carmona:

"la significación se produce siempre que una cosa, materialmente presente ante la percepción de un destinatario, represente otra a partir de reglas subyacentes. Ello implica que debe existir un código que establezca una correspondencia entre lo que el signo representa y lo representado, pero también, y sobre todo, que la cosa representada no tiene por qué existir ni ser sustituida, de hecho, en el momento en que la represente el signo sustituto significante de otra cosa." (Carmona, 1993: 120)

Es en este sentido que resulta singularmente importante para nuestro propósito el replanteamiento de la propuesta saussureana llevada a cabo por Helmslev (1943), quien sustituye la tríada signo/significado/significante establecida por F. de Saussure, por la de función semiótica/expresión/contenido. Al respecto, como afirma Eco (1976), cuando a través de un determinado código se relacionan elementos de un sistema transmisor (nivel de la expresión) con elementos de un sistema transmitido (nivel del contenido), se produce la significación a través de la aparición de una función semiótica.

Esto es: por un lado, existe función semiótica toda vez que una expresión y un contenido entran en correlación (en que ambos niveles se convierten en funtivos de dicho sistema de intercambios); por otro, existe signo cada vez que nos encontramos con una correlación de este tipo y que es reconocido como tal por una comunidad humana. Cada uno de dichos niveles del signo (la expresión y el contenido) admite a su vez la posibilidad de ser aprehendido desde lo formal y lo sustancial. Coincidiendo en esto con Saussure, respecto de que la lengua es forma y no sustancia, Hjelmslev postula que la forma semiótica es una invariante que da cuenta de la red relacional que define las unidades, y que la sustancia semiótica, en cuanto soporte de la significación, es una variable ${ }^{22}$. Vale decir

\footnotetext{
22 En síntesis: una determinada forma (textual, discursiva, narrativa, por ejemplo) puede manifestarse a través de muchas sustancias (fónica, gráfica, gestual, audiovisual...), pero no a la inversa. Fundada también en estas categorías, según sostuve: "nuestra perspectiva de abordaje [de las prácticas educativas] parte en consecuencia de dos supuestos fundamentales, relacionados entre sí: (a) Las construcciones discursivas de carácter didáctico
} 
que, en tanto manifestación sígnica, el texto fílmico (en vez de caracterizarse sólo por su materialidad física, o de individualizarse por improntas propias de una entidad semiótica fija) se constituye en espacio textual de encuentro de diversos elementos in(ter)dependientes, los cuales proceden de diferentes sistemas códicos que logran correlacionarse mediante asociaciones de carácter provisional o transitorio. Así redefinido en su constitución se pueden concebir e identificar, en el interior mismo del signo textual fílmico, por un lado, las operaciones de representación y de significación, toda vez que de esta (nueva) manera es posible introducir ciertos mecanismos que permiten explicar la alteración de la segunda (noción) en función de un específico contexto dado.

Pero a su vez, en ambos planos constituyentes del signo textual fílmico (el contenido y la expresión) podremos reconocer su materia, su forma y su sustancia. La materia de la expresión se asocia con la naturaleza del tejido (de la expresión cinematográfica) en que se recortan sus elementos significantes, de manera tal que cada sistema de significación (el sistema fílmico, por ejemplo) se realiza a través de una o de varias materias expresivas ${ }^{23}$. Precisamente, la peculiar productividad de la expresión cinematográfica reside en la heterogénea combinatoria de las diferentes materias que la integran, y que se dan organizadas, moldeadas y articuladas de singular modo, para ser utilizadas

no sólo podrían ser pensadas como estructuras funcionales, operatorias y transpositivas de distintos contenidos disciplinares específicos, sino también, como un campo de estrategias discursivas que sostienen los sujetos que interactúan en la puesta-en-escena educativa, cuyas interacciones también producen específicos contenidos diferenciales, a menudo implícitos o sobrentendidos. (b) El reconocimiento y análisis de tales procedimientos formales no sólo resisten la simplificadora interpretación de lo evidente, sino que permiten reflexionar sobre cuestiones que (...) anteceden al efectivo funcionamiento de las prácticas empíricas" (Caudana, 2004: 56).

${ }^{23}$ La tradicional caracterización e individualización de los lenguajes reposa en criterios sustentados en su materia de expresión: así, cada lenguaje posee en propiedad una materia de la expresión o una combinación específica de ellas. En cuanto al cine, la manifiesta heterogeneidad de su materialidad expresiva combina cinco materias diversas (Ch. Metz, 1973): dos se localizan en su banda-icónica (múltiples imágenes fotográficas móviles, organizadas en series continuas, y notaciones gráficas, que a menudo las sustituyen o se superponen con aquellas), y las otras tres corresponden a su banda-sonora: sonido fónico, musical y analógico. En sentido estricto, salvo el caso de la imagen móvil, las restantes materias expresivas cinematográficas son compartidas con otro u otros lenguajes (lingüístico, fotográfico, musical, etc.). 
como elementos de significación. La materia del contenido por su lado, que el cine comparte con los demás fenómenos de naturaleza semiótica, se asocia igualmente con el tejido semántico (de los contenidos); esto es, con las manifestaciones propias del universo (global) del sentido.

Respecto de la forma de dicho contenido: es la que entra en correlación con los particulares modos en que, dentro de un determinado marco sociocultural, se singulariza y especifica aquel mundo (general, posible) del sentido a través de diferentes registros y categorías: oposiciones, diferencias fílmicas. La organización y distribución de las mismas otorgan pertinencia al característico tejido semántico de un texto cinematográfico dado. Esta forma del contenido, a su vez, necesita ser transcripta (transpuesta, transfigurada) a través de los significantes que constituyen una materialidad expresiva dada. Esto es: la pertinencia de su carácter (semántico) permitirá establecer también un correspondiente lugar (gramatical) para la aparición de una forma de la expresión... De un sistema semiótico particular que permita explanar ciertos criterios de organización y articulación de los lenguajes significantes que participan en el filme: modos de relacionar imágenes y palabras, movimientos y desplazamientos de la cámara, selección y empalme de planos, etc.

En los dos casos, la sustancia conceptual y expresiva del texto fílmico comporta la (re)asignación de las respectivas materias, pero en tanto que formadas... Lo sustancial del filme surge, así, al proyectarse la forma sobre la materia, como si una (concreta) red o repertorio de interacciones (posibles) se proyectara sobre una superficie ininterrumpida de abiertas e ilimitadas posibilidades... Sustancias del contenido y la expresión de un texto cinematográfico, entonces: singulares modos de conceptualizar y codificar sus específicos significantes, en tanto que posibilidades ya repertoriadas del efectivo contar y lo efectivamente contado... Pre-textos, quizás, para contribuir (alguna vez) a los posibles señalamientos de una semántica discursiva de las narrativas fílmicas... Formas del contenido y la expresión: productividad de flujo de ciertos observables morfosintácticos, eventual fecundidad en la detección de elementos configurativos (formativos) del cine... Posición más o menos estable, para pensar (desde ahora) en parámetros narrativos de una gramática fílmica entendida como producto y producción, sistema y proceso... 


\section{DIÉGESIS, RELATOS, NARRACIONES CINEMATOGRÁFICAS}

Oportunidad, por cierto, de ir recortando ${ }^{24} \mathrm{y}$ concluyendo respecto de estos temas. Precisamente en este momento de mi interlocución (pretexto habido del texto) que demandaría ahora, como en su oportunidad se hizo con la reflexión sobre el discurso, amplificar la escucha teórica. En trance (gramatical) mismo de impugnar la noción de contenido, susceptible de ser aislado de su enunciado sin remitir (necesariamente) al acontecimiento de la enunciación (Benveniste). Porque más que "la agregación de una forma a un contenido prexistente, de un modus a un dictum, 'lo que se dice' es indisociable del cómo de su enunciación..." (Arfuch, 2002: 199)

En este contexto de presupuestos e hipótesis iniciales para la elaboración del concepto de signo textual narrativo y, a partir de ello, la delimitación de algunos principios para el desenvolvimiento de una gramática fílmica, procuraré precisar finalmente las nociones de diégesis, historia, relato, narración y narrativa, tal como las comprendo e interpreto en su aplicación posible a las producciones textuales del campo cinematográfico.

\footnotetext{
${ }^{24}$ Muchas cuestiones sin embargo quedaron (sin decir) en el recorrido. Me hubiera interesado por ejemplo destinar algún espacio mayor a cierta prototeoría insular, singular y fragmentaria, aparecida en los ` 60 y recientemente revalorizada [cf. Casetti, ob.cit]. Vinculando la definición de "cine como lenguaje" con la recuperación de una noción de relato como "orientador de imágenes y sonidos", los aportes de Laffay [(1964) Logique du cinéma. Paris: Masson et $\mathrm{Cie}$ s se perfilan en la actualidad como antecedentes palpables de una narratología cinematográfica, que se insinúa en la misma línea de "lingüística externa" o "gramática inter / transtextual" que antes mencioné como particularmente prometedora y precursora. "La realidad nunca es estética por sí misma. Si el cine es un arte (dice Laffay), tendrá que ser algo más que una reduplicación del mundo existente". La dimensión narrativa se establece como instancia necesaria y constante para efectivizar esta específica productividad: legitima y "legibiliza" la realidad transpuesta, reorganiza las componentes del universo representado, formaliza u otorga "estructura y perspectiva" en relación con los materiales utilizados, etc. Esto es: el relato no sólo transmuta "al mundo real en eficaz ilusión", sino que otorga sentido al universo representado; no sólo se constituye en filtro constructivo para la representación, sino que se convierte además en auténtico discurso. Anticipando a la vez aspectos narratológicos que, en los '80, se conceptualizarán como instancias propias del enunciador o del autor implícito, reconoce en toda película la presencia de una suerte de figura abstracta, de grand imagier o maestro de ceremonias que, además de "guiar (literalmente) el juego cinematográfico", encarna el acto mismo de hacerse ver y entender por parte del filme, que lo moviliza en tanto que discurso. En síntesis como dice F. Cassetti, al ser "el tejido del relato de naturaleza discursiva [el cine, unido a él] se convierte en un mecanismo lingüístico" y "encuentra en el relato un cómplice necesario y, al mismo tiempo, una razón más para ser un lenguaje" (Cassetti, 2000: 82).
} 
> Por narrativa fílmica entiendo una cierta dimensión analítica constructiva, en situación de desarrollo, perteneciente al orden singular de las prácticas narratológicas: un complejo, compuesto y dinámico sistema de producción significante (que a su vez puede ser contado, explanado y narrativizado) en el que, de manera sincrética, interactúan historias, relatos y narraciones. Expresado en otros términos: una narrativa en el cine constituye también un tipo particular de textualidad, procesual y dinámica, que da cuenta del desenvolvimiento del acto de producción de un relato fílmico; o lo que es lo mismo, del proceso discursivo, de la construcción de sentido a través de la cual se pone en pantalla una determinada historia relatada. En síntesis, a través de esta caracterización provisoria procuro definir a las narrativas cinematográficas, en términos de gramática narracional, como procesos sistémicos genéricos y globalizadores. Es decir, en tanto constructos (descriptivos, explicativos e interpretativos) constituidos por tres componentes analíticas interdependientes, en la consideración (gramatical) de lo fílmico como sistema y como proceso: las formas (de una expresión y de un contenido narrativos) y el acto mismo de producción significante ${ }^{25}$.

$>$ En dicha textualidad narrativa se articulan, en principio, una dimensión histórica y una dimensión discursiva: es decir, un contenido narrativo (un encadenamiento relacional de situaciones, aconteceres, etc.) y una forma expresiva mediante la cual se manifiesta y comunica dicho contenido ${ }^{26}$.

${ }^{25} \mathrm{Cfr}$. el diagrama siguiente, a través del cual procuro representar las mencionadas dimensiones analíticas y sus correspondientes articulaciones.

${ }^{26}$ Aunque los orígenes de estas nociones ya se encuentran en la Poética aristotélica, son los formalistas rusos (especialmente Tinianov, Sklovski, Tomachevski, años 1923 - 1928) quienes propusieron distinguir, en el marco de la fábula (de la organización del material narrativo), entre historia y trama. La "historia" representa el momento en que el material narrativo no ha recibido todavía una configuración textual; en ella, los "motivos" (unidades narrativas mínimas) se organizan de acuerdo con un patrón lógico y cronológico. La "trama", por el contrario, alude a la etapa en que el material se encuentra textualmente configurado, esto es, provisto de una forma. Por la misma época, la crítica literaria anglosajona consagró los términos story y plot (cfr. Forster, 1927), respectivamente, para aludir a la distinción establecida por los formalistas. Reconsiderando en este nuevo entorno la cuestión de las "articulaciones" discursivas cinematográficas, Gaudreault sostuvo que la primera articulación (establecida entre fotogramas y producida por la cámara filmadora) se localizaría en proximidades de la "historia", considerando el carácter invisible y transparente de su discontinuidad. Contrariamente la (segunda) articulación, que se establece entre planos y resulta "visible" porque es producida por operatorias de montaje, se situaría en el campo del "discurso" fílmico. 


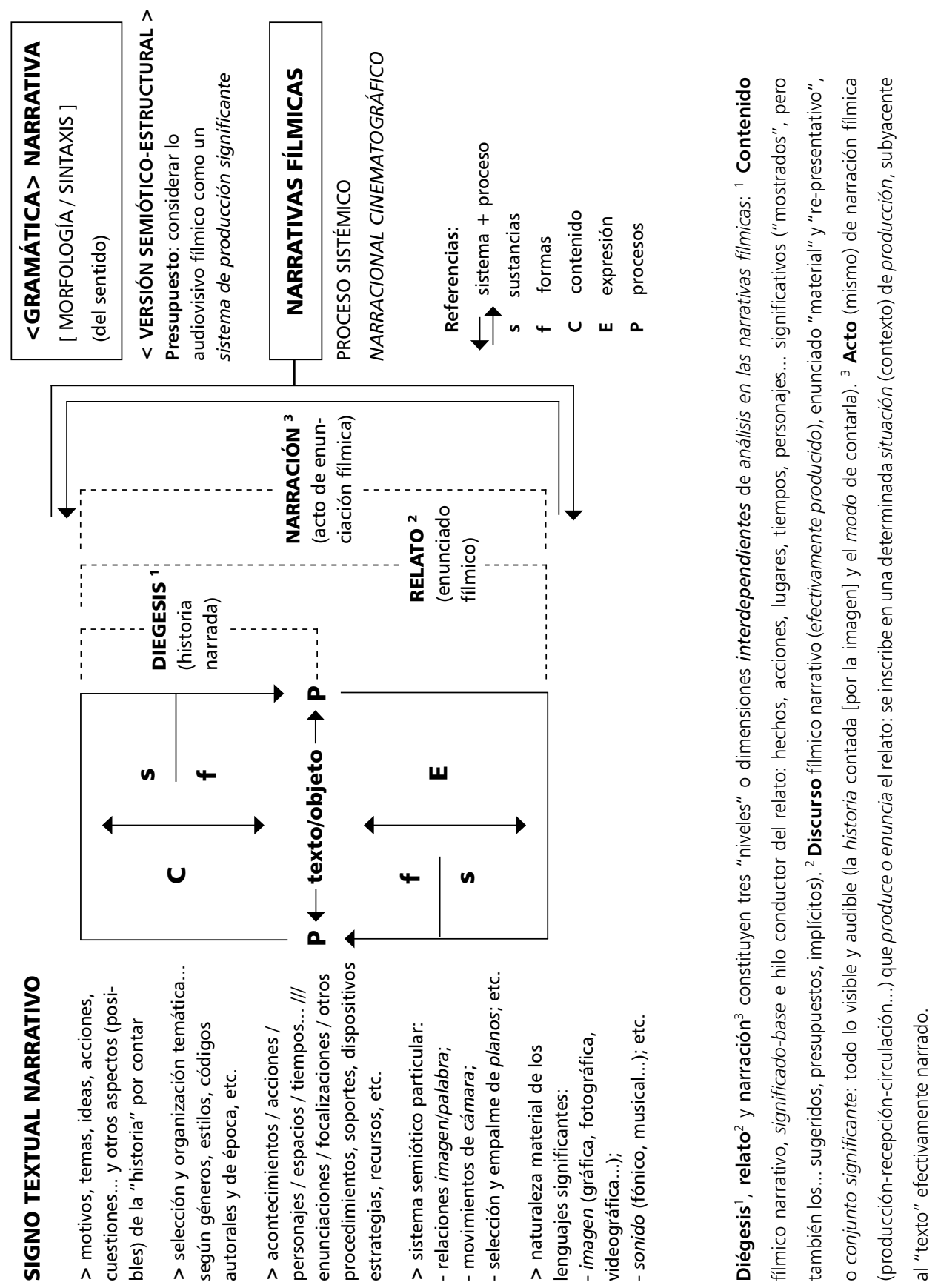


Más simplemente, un qué y un cómo (se narra): la historia que se cuenta, identificada con lo narrado, que así se distingue del relato o discurso que (la) narra. Para abordar y problematizar estas cuestiones del contenido y la expresión en el caso específico del cine, Metz recupera aquellas distinciones entre historia y discurso inicialmente formuladas por E. Benveniste, a fin de destacar por ejemplo la particular discursividad que reviste la categoría denominada cine clásico o tradicional: la de un discurso que tiende a presentarse (a sí mismo, simplemente) como una historia. Esto es, de un tipo de cine que procura suprimir las marcas de la enunciación (cinematográfica) o disimular las huellas ostensibles del trabajo discursivo y de su proceso de producción textual, para sólo (re)presentarse como una historia que nadie cuenta, ocurrida sin tiempo ni lugar (enunciativos), y desplegada sin visibles particularidades (enunciadas) de modalización.

$>$ Pero lo cierto es que, en el cine así como en las demás prácticas narratológicas, sin acto narrativo (narración) no existe enunciado (relato) ni tampoco contenido narrativo (historia o diégesis). El contenido narrativo, por otra parte, a menudo asociado a la vez con las nociones de historia y de diégesis (expresión griega que suele traducirse como historia contada ${ }^{27}$ ), no sólo remite a los elementos mostrados por el filme sino que refiere a la totalidad exhibida y/o implícita del universo semántico o significado (de y por la película). Esta específica inteligibilidad (para la cual reservaré la denominación general de diégesis, o de universo diegético global y coherente dentro del cual se selecciona, construye y desarrolla una historia particular: secuenciación de acontecimientos, seres implicados en los mismos, sucedidos en determinado tiempo y lugar, etc. $)^{28}$

\footnotetext{
27 Propongo en cambio asociar la noción de diégesis al concepto de mundo posible, tal como resulta de la reflexión producida (desde hace algunas décadas) en el campo de la filosofía del lenguaje, la lingüística y la teoría literaria mismas. Popper distingue tres tipos de mundos: el físico, el de los estados mentales y el de los productos mentales (entre los que se encuentran las creaciones artísticas). La noción de "modelo de mundo" se presenta como un concepto explicativo por medio del cual se pretende dar cuenta de la realidad global y, especialmente, de las relaciones que median entre el mundo efectivo y los mundos alternativos. Cada uno de dichos "modelos" de mundo establece una particular imagen de la realidad, construida de acuerdo con las instrucciones propias de ese mundo, por lo que sería "interpretable" como un conjunto de instrucciones necesarias para acceder a dicho "universo".

${ }^{28}$ Tomando por caso una película del "género" policial: su historia puede limitarse a una narración sobre enfrentamientos entre grupos rivales, y a la mostración de determinados lugares, acciones y personajes significativos. Pero
} 
convierte al contenido narrativo en un objeto de conocimiento en sí, que le confiere una cierta autonomía en relación con el relato que lo recorta y actualiza.

$>$ El relato fílmico, en consecuencia, constituye todo lo visible y audible en una película, el conjunto de los elementos significantes puestos en pantalla. Esto es: el enunciado material que (a la vez que incorpora recursos o procedimientos específicos del cine, y presupone una situación de producción, un acto de narración que lo produce) ensambla y articula también, en su compleja configuración estructural, tanto los elementos diegéticos que corresponden o se deducen del mundo de la historia contada, como aquellos aspectos ajenos $a$ él (es decir, los elementos no diegéticos) y/o introducidos desde afuera del universo significado (extradiegéticos). Por ejemplo, construcciones paratextuales, componentes musicales, recursos de montaje, etc. Dicha pluralidad de configuraciones significantes, tanto visuales como sonoras, contribuyen a la construcción del discurso fílmico conforme también con una estructura gramatical subyacente que, en cierto modo, asegura o garantiza su legibilidad. Algunos parámetros de causalidad (relaciones lógicas explícitas o conjeturales entre causas y efectos), espacialidad y temporalidad (entre mundo diegético y universo representado, según categorías de orden, duración y frecuencia ${ }^{29}$ ), no sólo permiten orientar tal legibilidad de una historia contada, sino que además dan cuenta de la coherencia o ligamen interno del texto fílmico, del carácter necesariamente (s)electivo del relato cinematográfico. De su condición, en síntesis, de discurso efectivamente producido:

\footnotetext{
estos aspectos, sumados a otros elementos tal vez sólo sugeridos o presupuestos a lo largo del relato (el origen de la rivalidad, por ejemplo), permitirían reconstituir el universo diegético global en el que se recorta la "historia contada": el contexto histórico y sociocultural de los acontecimientos relatados, del espacio urbano en que se localizan, de la temporalidad (enunciada) en que se sitúan: Chicago, años '30, crisis económica, entre otros...

${ }^{29}$ Muchas veces un relato literario o fílmico selecciona períodos de su historia narrada, para omitirlos en parte de su desarrollo o reiterarlos en más de una oportunidad. Esto demanda un esfuerzo interpretativo por parte del lector o espectador, que debe tratar de reconstruir la historia a partir de los indicios que le ofrece el relato. G. Genette (1972) da cuenta de los acontecimientos presentados por el relato fílmico en un orden cronológico y procura asignarles una duración y una frecuencia.
} 
“La imposibilidad de establecer relaciones precisas de causalidad, tiempo o espacio entre planos sucesivos impediría que éstos pasaran del orden de la simple mostración al de la narración propiamente dicha. La dificultad para recomponer la estructura narrativa del film llevaría, en casos como éste, a una lectura 'independiente' de cada fragmento, como si se tratara de una acumulación de descripciones desligadas entre sí o de 'embriones' de relato discontinuos. Desde ya que esta desconexión puede responder a otra forma de discurso (habitual en el 'lenguaje' del videoclip, por ejemplo)" (Bettendorff y Prestigiacomo, 1997: 105).

$>$ Analizar la discursividad narrativa de un film, en síntesis, consistirá en abordar las relaciones existentes entre contenido diegético y contenido narrativo específico (de la historia narrada), y entre historia y relato (fílmicos); pero además, y fundamentalmente, en estudiar las triangulaciones posibles de ser explicitadas y explanadas entre historia, relato y narración cinematográfica.

$>$ En un sentido amplio podrá entenderse por narración cinematográfica (como dije antes) al acto de producción significante o, más específicamente, al acto de enunciación de un relato fílmico, ya que la instancia narrativa siempre se liga, vincula e implica con el problema perteneciente al orden general de lo enunciativo. La enunciación constituye en principio (1) un proceso que subyace a todo discurso, sea cual fuere su tipo y su soporte significante, y que (2) se caracteriza por la construcción (discursiva) de subjetividades. En cuanto a lo relacionado con el primer aspecto: la enunciación comprende, en consecuencia, tanto la producción misma del discurso como el mismo discurso producido. Puede manifestarse, por lo tanto, en una dimensión específicamente enunciativa (esto es, vinculada con la situación de discurso, con las condiciones propias de su aparición o construcción) como en una dimensión enunciva (vale decir, en un sentido más restringido, que se relaciona con el relato o discurso mismo, efectivamente producido $)^{30}$. Cuando hablo aquí de narración fílmica

\footnotetext{
${ }^{30}$ Entre otros aspectos susceptibles de ser deslindados y analizados en este campo descriptivo se encuentran, por ejemplo (al menos en el contexto teórico-metodológico de la semiótica discursiva greimasiana), el de las componentes actoriales o de la puesta actancial en discurso narrativo. Tales componentes comprenderían, en el caso de la dimensión enunciativa, la consideración de las parejas opositivas enunciador/enunciatario, narrador/narratario,
} 
estoy haciendo referencia a la primera dimensión (enunciativa) de la instancia narracional, toda vez que la segunda (la narración enunciva) corresponde a un desarrollo que tiene lugar en la interioridad del relato construido ${ }^{31}$. Dicho proceso enunciativo se caracteriza además, y de manera específica (decía), por la construcción de determinadas identidades subjetivas dentro del discurso: la de un sujeto enunciador por ejemplo que se "apropia del aparato formal de (un) lenguaje" (Benveniste), para así diferenciarse de un otro (su enunciatario) y poder referir o construir referencias del mundo exterior (al propio discurso). Esta cuestión de las subjetividades discursivas se ha convertido en uno de los aspectos teórico-metodológicos más problemáticos para abordar el análisis de la textualidad cinematográfica ${ }^{32}$. Dada su complejidad, así como sus considerables presupuestos, derivaciones y matices, excede largamente el carácter principista de esta postulación inicial.

Sólo diré que, en tanto tales, las identidades discursivas de narrador o enunciador (correspondientes a esta instancia narrativa), no tienen que ver con posibles figuraciones empíricas (autor o director, equipo realizador o de producción del film...), sino que las mismas se asocian con funciones o actividades de selección, jerarquización, organización, etc. de determinados procedimientos o recursos (nuevamente formales) relacionados con la configuración y conducción del relato fílmico.

Así, la narración fílmica podría ser definida como dispositivo articulatorio de un doble proceso de enunciación cinematográfica. Por un lado, como procedimiento progresivo de "anulación [o de disimulación] de todo lo que está

etc.; respecto de la dimensión enunciva correspondería en cambio hacer referencia a las relaciones existentes entre los personajes o actores de un determinado discurso o relato.

${ }^{31}$ Respecto de esta segunda dimensión, y en directa relación con el concepto de representación fílmica al que antes aludíamos, la instancia narrativa (del relato) puede estar representada o asumida por uno o más actores o personajes (sujetos del enunciado), e incluso disimularse o desdibujarse, detrás de un aparente grado cero narrativo. ${ }^{32}$ Aquellas problemáticas tienen que ver, por ejemplo, con las dificultades para establecer posibles equivalencias entre las enunciaciones (subjetivas y no subjetivas) lingüística y fílmica, y sus correspondientes correlatos: la sobredeterminación del espacio subjetivo en el cine (el sujeto que mira y que no puede a la vez mirarse mirando...); la cuestión del punto de vista en relación con las distancias y ángulos de observación (otra vez de las miradas); las particulares modalizaciones de la iconicidad y la escucha cinematográficas (focalización, ocularización, auricularización); etc. 
detrás de la cámara [aunque tal acontecer enunciativo resulte de muy dificultosa explanación y explicitación]; y por otro, "como el 'conjunto de elecciones abstractas' que guían el modo de percepción del enunciador, [y que] dependería, en rasgos generales, de la internalización del contexto en el relato" (Bettendorff y Prestigiacomo, 1997: 127-128) 33 .

Por todo lo expresado podría también sostenerse que, en definitiva, la "instancia narrativa" (de la narración cinematográfica - de toda narración, en realidad) se constituye en presupuesto subyacente de lo efectivamente narrado (por el relato fílmico -por todo relato). Que se localiza en el espacio textual mismo en que se articulan sus respectivas formas... del contenido y la expresión. Garantía suficiente, en consecuencia, de una relativa legibilidad de cierta ideología...

\subsection{REPERTORIO DE ACCESOS Y CLAVES DE LECTURA (SOBRE LAS PRÁCTICAS NARRATIVAS)}

La narratividad es un mecanismo subyacente a toda significación, a toda actividad humana significante..

\section{A. J. Greimas}

A partir de esta concepción greimasiana la noción de narratividad subyace, como huella permanente, en todo recorrido generativo de sentido (textual)... Esto es, en tanto saber o razonamiento discursivo que se asocia con todo depósito de

${ }^{33}$ En efecto, todo filme da cuenta, independientemente de su manifestación (sea esta ficcional o documental, por ejemplo), de las características sociales e individuales, públicas o privadas, etc. de un determinado mundo (al que denominamos universo diegético), por más que ese mundo nunca haya existido ni existirá, o recién esté por existir en el futuro. En este sentido me importa destacar los planteamientos de F. Martínez Bonati (1992), quien establece tres tipos de objetos (reales, ilusorios y ficticios) en las construcciones de ficción, y diferentes niveles o grados de combinación entre ellos. Los objetos "reales" son empírica o históricamente verificables; los "ilusorios", fruto del autoengaño o confusión, ilusión sensorial o falsa interpretación; y los "ficticios", proceden de una voluntad creadora consciente de estar dando forma a un objeto no real. Así pues, en la construcción "artística" de una obra de ficción, todo es ficticio, en tanto que los puntos de anclaje de sus objetos se dan con el ámbito de la imaginación; excepto la construcción misma del propio texto, en cuanto imagen o modelo del mundo. Precisamente, de esa desvinculación progresiva con la realidad efectiva procede la riqueza y ambigüedad del objeto ficticio, de todo texto artístico... 
formas significantes... En sus frecuentes intercambios con Greimas, Ricoeur ha logrado subrayar aún más su pensamiento a propósito de que, lo que aprendemos a utilizar en nuestra vida de sujetos que construimos significaciones, es (en realidad) una inteligencia narrativa..., y una determinada percepción del tiempo que nos constituye en tanto que sujetos. Tal vez sí, tal vez no... esta (idea de) narratividad esté inscripta en los objetos y sucesos del mundo, pero lo cierto es (o al menos lo parece) que sólo el lector de narrativas sería capaz de descubrirla y (hasta, quizás, de) explicitarla... Con este inusitado propósito buscan comprometerse los trabajos reunidos en este volumen, todos ellos producidos en el marco del proyecto sobre indagaciones narrativas que actualmente dirijo. Con alguna persistencia, eso sí, por recuperar perspectivas y enfoques singulares acerca de la cuestión, o por practicar ciertas ejecuciones respecto de lecturas, análisis e interpretaciones de diferentes relatos situados en contexto social.

Con actitudes de entusiasmo y disponibilidad de las teorías que, si bien han sido (fervorosamente) ponderadas y favorecidas por determinados campos humanísticos y sociales, no suelen aplicarse con el mismo énfasis o impulso a la hora de describir y comprender situaciones propias de la enseñanza y la investigación en el dominio. Es que la pretensión de contribuir al desarrollo y enriquecimiento de los estudios narratológicos, en modo alguno pronostica facilidades para poder entramar y desplegar un recorrido argumentativo más o menos sólido, estable y fundado, además de exponerlo en una forma relativamente orgánica y sistemática. Por tratarse, incluso, de mecanismos casi naturales y espontáneos del contar o del narrar, tal vez pudiera pensarse (al menos inicialmente) en simplificaciones temáticas excesivas, o bien en caracterizaciones exentas de riesgos u obstáculos. Todo lo contrario. Las complicaciones existen, son numerosas y de diversa índole: teóricas, metodológicas, epistemológicas...

Por los incontables laberintos de estas dificultades (casi digo inconfesables, suponiendo que, casi en su final, pudiera rescatarse algún mérito) se anduvo bifurcando y solazando la escritura de este primer capítulo del volumen, mientras disimulaba su condición de reflexión teórica enmascarada en ciertas aplicaciones gramaticales sobre el simulacro fílmico. Los siguientes trabajos, además de explicitar cada uno de ellos sus propios presupuestos teóricos, abordan aquellas mismas problemáticas pero en textualidades diversas, heterogéneas, plurilingües: filmes documentales, discursos videoclípticos, bionarrativas 
historiográficas... incluidos el mismo proyecto ${ }^{34}$ de investigación y la propia práctica escritural como objetos de reflexión semionarrativa.

Porque para poder mostrarse, según cómo opera la creencia, no se necesitan del todo ni determinaciones teóricas ni circuitos excesivos de reconocimiento ni tipologías, categorías o distinciones operacionales. Casi lo contrario: se precisa sólo poner en cuestión los aparentes esquemas invulnerables de la certeza y la referencia... Por eso es que se piensa (hasta mi empecinado convencimiento actual) en el incalculable valor productivo, transpositivo o transfigurativo de las narrativas... como vectores de significativa relevancia para poder contribuir al avance de unas cuantas investigaciones propias, específicas del campo humanístico, social y cultural. Et tout le reste (diría Verlaine) est littérature...

\footnotetext{
${ }^{34}$ En el diseño inicial de esta publicación se incluía además otro capítulo titulado "Recorrido generativo de un proyecto de investigación: de los significados al relato y del discurso a su narrativa", que intenta reflexionar y ejecutar(se), en términos semionarrativos, a propósito de los orígenes, desarrollos, continuidades y articulaciones de esta otra "historia de vida": el proyecto mismo de semiótica. Diferentes razones nos hicieron desistir de aquel propósito inicial: la excesiva extensión del sumario ya preparado para este número, en primer lugar. Pero también la inminente conmemoración de los XX años del proyecto (que se inició en el '87 como un diseño de semiótica teatral) y la selección del eje temático de nuestra próxima edición, actualmente en preparación: las narrativas y el teatro. Algo así como una retroducción narrativa al origen, en simultáneo con otra "vuelta de tuerca sobre el teatro".
} 